\title{
Contingency, Absurdity and Human Conflict in Sartre's Philosophy
}

\author{
Dagnachew Assefa*
}

\begin{abstract}
This article is centered on two of Sartre's literary works: "Nausea" and "No Exit" along with his dialectical theory of the 'Look' in Being and Nothingness. I believe that these three texts represent not three distinct perspectives but rather different sets of approach to the same problem i.e. the phenomenon of human relationship. It is with this point in mind that I develop the following interrelated claims. First, even though Sartre intended to bring a new language and mode of articulation in his later works, the fundamental features of his philosophy remained the same. Thus, issues that are foundational to his early writing including the selflother relationship, the for-itself as project, the contingent reality of the world, the resistance of the in-itself/ materiality all figure high in his later writings as well. Second, as opposed to any social philosophy which accepts the possibility of a harmonious relation between human beings Sartre perceived the essence of human relations not as mitesein ('being-with'), but rather as conflict. I submit that the source of Sartre's problem lies in his very model of social relations given that his social ontology does not allow him to incorporate what Maurice Marleau-Ponty calls the "inter-world". This paper is also informed with the belief that although Sartre the intellectual and the creative artist are closely joined together, essentially, the novelist is much more assuring than the philosopher. Thus, even when he is not writing a literary composition proper he displays a unique talent of putting his philosophical ideas in artistic and dramatic terms. I use Sartre's phenomenological description of the dialectic of the "look" (Le Regard) to demonstrate this point. The final section of the paper is devoted to a critical examination of Sartre's philosophical positions developed in the works discussed above.
\end{abstract}

Keywords: The "look", being-for-itself, being-for-others, self-consciousness, absurdity

DOI: https://dx.doi.org/10.1314/ejossah.v16i2.4

\footnotetext{
*Assistant Professor, Department of Philosophy, College of Social Sciences, Addis Ababa University, Email: dagnachewassefad@gmail.com; Tel: +251910296547, P.O. box 1176/ Addis Ababa
} 


\section{Introduction}

The central aim of this article is to bring to light Sartre's analysis of key existential issues which is located in his early writings. There are obviously different points of entry in to his thought, for my part I shall pursue my exploration by focusing on the following themes: (a) the confrontation of consciousness with existence (Nausea); (b) the question of the existence of the other (Being and Nothingness) and his Hobbesian depiction of human relationship (No Exit).

In the interests of clarity and plausibility, I shall present my account in stages always having the dialectal connection between beginning and end in mind. In the first stage, I shall deal with the phenomena of existence as portrayed in his famous novel Nausea. The central configuration of the novel is about the confrontation between consciousness and existence. Sartre's ontology is based on the distinction between two different types of beings: the being of objects of consciousness and the being of consciousness. He calls the former Being-in-itself and the latter "Being-for-itself."

Nausea emphasizes one side of the duality of beings, i.e. on the being of object and existence. In his phenomenological account of existence, Sartre shows that there is much more to existence than we ever acknowledge in our everyday life. Existence is "superfluous," "contingent," and, above all, "absurd." Any attempt by philosophy, religion and science for that matter to hide this and introduce necessity to existences will be a futile exercise.

In the second stage, I shall examine the issue of the existence of the other. Sartre's theory of intersubjectivity begins with a critical examination of the classical school which had a close affiliation with Cartesianism. He found this school to be highly susceptible to Idealism and Solipsism. Later, in Hegel, Husserl and Heidegger, Sartre found the essential corrective measure against the classical position known as the doctrine of analogy. From the above mentioned thinkers he took two essential points that also became the bases for his philosophical formulation: (i) that the self/other relationship is internally connected and (ii) that this connection is found in the very state of conscience.

In the third stage, I shall deal with Sartre's third region of being, namely Being for others. To begin with, the other is encountered not constituted. The sheer appearance of the other generates suspicion and alarm since we both mutually desire "the human world."

Secondly Sartre's definition of the other as "the one who looks at me" is presented in the short drama "No Exit." In the play, human relationship is fraught with struggle and conflict much more like Hobbesian state of nature. 
In conclusion I want to advance the claim that Sartre's theoretical undertaking is contingent to a large extent upon the grounds laid out in his earlier philosophical works.

\section{Experience, existence and reality}

Robert C. Solomon is right on the mark when in his imaginary interviews with Sartre, Heidegger and Camus made Sartre claim that: "My novel Nausea, which I wrote in 1938. I still think it is the best thing I ever wrote" (Solomon, 1981, p. 13). Most scholars share Professor Solomon's judgment. For instance, William Barrett, author of "Irrational Man" consider Nausea as Sartre's best novel. On the philosophical plane, the novel is also taken to be as an important introduction to Sartre's phenomenological ontology that was to be worked out later in Being and Nothingness.

The structure of the novel is fairly simple. The main character of the story is Antoine Requentin who initially set out to write a book about the life of an eighteenth-century adventurer, the Marquis de Rollebon. At the beginning of the novel, the reader is reminded that the publishers are reproducing the diary they have found in Antoine Requentin's papers. The core theme of Requentin's journal revolves around "his account of how his relationships with the world, with things and people have profoundly changed" (Daigle, 2010, p. 27). In the end, though, his initial project did not see the light of day. Two major factors frustrated Requentin in his bid to play a historian. First, his time was consumed in trying to come to terms with a unique and alarming experience that had engulfed his existence. Second, he realized that in the absence of any meaning of his own existence, it would be futile to indulge in the construction of the events of another person's in life.

What is the nature of this strange experience for Requentin? He tells us that the incidents that triggered this unusual experience are simple and ordinary. There are different instances on how this odd experience occurs. While walking on a beach, his attempt to throw a pebble into the sea failed. His entry in his journal reads "Saturday the children were playing ducks and drakes and, like them, I wanted to throw a stone into the sea. Just at that moment I stopped, dropped the stone and left. Probably I looked somewhat foolish or absent-minded, because the children laughed behind my back" (Sartre, 1959, pp.7-8).

On another occasion he was not able to perform his usual habit of picking up a piece of paper that places on the pavement. He says: "I saw a piece of paper laying beside a paddle. I went up to it. The rain had drenched and twisted it, it was covered with blisters and smelling like a burned hand...I bent down, already 


\section{Dagnachew Assefa}

rejoicing at the touch of this pulp, fresh and tender, which I should role my fingers into grayish balls...I was unable" (Sartre, 1959, p.17).

Furthermore, he found out that objects have lately acquired a strange and unpleasant appearance. In his eyes, it is as if existence had become abnormal and out of the ordinary. Also to his surprise, objects gave him the impression of undergoing a radical change. Somehow everything he sees and touches around him appeared unpleasant. Roquentin scratched a note in his diary:

A little while ago, just as I was coming into my room, I stopped short because I felt in my hand a cold object which held my attention through a sort of personality. I opened my hand, looked; I was simply holding the door knob. This morning in the library when the selfthought man came to say good morning to me, it took me ten seconds to recognize him. I saw an unknown face, barely a face. Then there was this hand like a fat worm in my hand. I dropped it almost immediately and the arm fell back flabbily. (Sartre, 1959, p.11)

Objects are transformed into undifferentiated hip of masses; they are without form, symmetry and regularity. Finally, in the world of Roquentin objects also seemed to have developed the power to make you sick: they bring a strange sensation that gives one "sweetish sickness" as Sartre describes it. Certain existential conditions usually exasperate this ailment; for instance, it struck when we are not standing on a sure footing in what we do and what we experience in life. Thus, it comes at a time when we stop taking things for granted and when we are apprehensive about something.

At first, he was not sure of the source of this strange discovery. Could it be in him? He asks: "the Nausea is not inside me. I feel it out there in the wall, in the suspenders, everywhere around me. It makes itself one with the cafe; I am the one who is within it" (Sartre, 1959, p.31).

As the story advances, he surely began to identify the real source of his predicament and nausea. Much to his surprise, he discovered that there was a connection between the alarming experience and the recurrent nausea that he was getting. He tells us that, "now I see: I remember what I felt the other day at the age of the sea when, I held that pebble in my hand. It was a kind of sickly sweet disgust. How unpleasant it was: And it comes from the pebble. I am sure of it. It 
passed from the pebble into my hands. Yes, that's it, that's just it: a kind of Nausea in the hands" (Sartre, 1959, p.31).

Nausea somehow points to existence. Roqentin encounters with existence lead him to metaphysical experience such as the experience of absurdity and contingency. Never before did Roquentin experience existence in such a manner. It seems that existence had opened itself to him for the first time. Now he thought he understood the full meaning of existence. What is it Roquentin newly discovered about existence that he did not know before? In what manner did the new experience affect him? What possible lesson did he gain from it?

His experience in the park is the most vivid expression of his encounter face to face with existence. While in a park sitting on a bench something hit him hard, his whole being was affected. It was just like a religious conversion. He puts it this way:

It left me breathless. Never, until these last few days, had I understood the meaning of existence. I was like the others, like the ones waking along the seashore, all dressed in their spring finery. I said, like them "the ocean is green; that white speck or there is a seagull: but I did not feel that it existed or that the seagull was an existing seagull; usually existence hides itself... if anyone had asked me what existence was, I would have answered in good faith, that it was nothing, simply an empty form... and then all of a sudden, there it was clear as a day; existence had suddenly unveiled itself' (Sartre, 1959, p.171).

He realized that there is much more to existence than he had ever anticipated before. Existence is like a mystery that will elude us until we remove our screen and try to grasp it intuitively. He also realized that up to now he had been forced to impose external attributes to things that were foreign to its essence. Requentin concluded that reality has the structure very far from the way we perceive it. The chief culprit here is language: that is, language and reality converge; our conventional disquisition fails to capture the truth of reality.

This critical perspective is in line with Sartre's short but interesting essay called "Intentionality" which he had written before. In that article Sartre claims that French Idealism greatly overstates the role of consciousness and human subjectivity and virtually eliminates any semblance of reality for the perceived object. Thus the object of the world loses its status of having an independent existence other than being a mere content of consciousness.

In Nausea, Sartre advanced the same critical argument against what he calls 'elementary psychology' which tends to reduce the world into consciousness. We 


\section{Dagnachew Assefa}

tend to embellish reality in a sophisticated or poetical way. His reflections on the beach about the ocean led him to the conclusion that the ocean had been humanized. What poets adore, what painters draw on their canvas does not exist. What we have in the sea is instead "black, knotty, mass, entirely beastly, which frightened me" (Sartre, 1959, p.171). Consequently, in order to come across the true face of the ocean, we have to transcend our anthropomorphic views that cover the reality of the ocean.

But then, what is the positive lesson that his vision revealed to him about existence: Existence is always something extra; it is difficult to capture the total essence of existence in words no matter how hard we try. Rational discourse cannot exhaustively capture the essence of existence. That is why Requentin believes that existence is always superfluous. In Sartre's words, "superfluous, the chestnuts tree there, in front of me, a little to the left, superfluous, the velleda. And I myself-soft, obscene, digesting, juggling with dismal thought...I am too superfluous" (Sartre, 1959, p.173). What then does the concept of "superfluous" connote? The terms suggest that we are unnecessary and contingent beings; that is, the world even more could have existed without us. Even what we consider as true is only "accidentally" true since it could have been untrue. In short, existence is not embedded nor necessary-it is rather contingent, absurd, and superfluous.

Regardless of what we think of it, everything is "de trope;" man lives in the realm of the absurd. For Sartre, both being-in-the world and the Being-of the world belong to the realm of the absurd. For him "contingency," "chaos," "absurdity," etc. are synonymous. These terms reflect the arbitrariness, purposelessness and aimlessness of being. In the end, the absurd has no ground for its existence. If existence is basically absurd, our effort to reject and hide this fact is fruitless. Requentin says “... 'absurdity' is emerging under my pen, and without formulating anything, clearly, I 'understood that' I had found the clue to existence, the clue to my Nausea, to my own life" (Sartre, 1959, p.173). Nausea offers a concerted effort to force us to accept the truth about existence even if it is disagreeable with us. But people who are not reflective enough about themselves and the world do not necessarily find this to be true. They find it hard to admit that existence is fundamentally absurd and that things exist in a contingent and non-necessary way. In fact they believe that they exist by necessity. Two classes of people are prone to reject the idea that absurdity and contingency underline the fundamental structure of all existing reality. This group is made up of 'philosophers' and the 'bourgeois', i.e. those who are high in the social ladder.

In order to hide and displace the idea of absurdity and contingency, philosophers invent the idea of order, reason and necessity but such an attempt is 
doomed to failure because the supposed reality they claim about does not exist in actuality. Such a world is illusionary: "But no necessary Being can explain existence: contingency is not a delusion, a probability which can be dissipated; it is the absolute, consequently, the perfect free gift" (Sartre, 1959, p.176). The Bourgeoisie, however, sees things differently. They hold that their Being is stamped with permanence and "necessity" that their social status and role in society affords them the right to exist. Sartre despises such groups and has nothing good to say about them.

On the other hand, Sartre believes that the poor, the Jews and the Negroes knew all along instinctively what Requentin had discovered intuitively. That is why he shows sympathy to those groups of people as opposed to the ruling class or bourgeoisie. Traces of Sartre's lifetime sympathy and support for the downtrodden is present in this novel. The philosophical message we get in the novel could be summed up in the following points: (i) Existence is fundamentally absurd and we need to accept this truth beyond any doubt. (ii) Existence is always 'extra' no matter how much we try, it refuses to fit into our descriptive mode. (iii) The categories of 'necessity' is our invention, hence the world is and could have existed without us. Here one could surmise that if Sartre is asked the old metaphysical question: 'why is there something rather than nothing'? I am sure that he would answer that 'there need not be anything at all'.

\section{Encounter of the self and the other: Descartes to Sartre}

Sartre deals with the crucial problem of human relationship in two stages. In the first stage, he examined the condition and possibility of the existence of others in Being and Nothingness and the second stage, he dealt directly with the issue of human relations in No Exit. The genesis and foundation of Sartre's theory of intersubjectivity begins in his notion of what he calls Being-for-others. It is an essential component of human existence whose validity as a concept falls entirely on the existence of other subjects. That is precisely why Sartre took his time to study and critique other theories that professed to have 'proved' the existence of others.

Sartre's theory of the "Other" begins with a critical examination of the classical school known as 'the doctrine of analogy' which had a close affinity with Cartesianism, and he found this school to be highly susceptible to idealism and solipsism.

The metaphysical legacy that Descartes left behind concerning the relationship between the mind and the body preoccupied subsequent philosophers for a long time. Cartesianism is based on two distinct but interconnected 
Dagnachew Assefa

philosophical positions. The first premise is that we know our ideas directly and immediately, whereas the external world is known to us via mediation and inferentially. Thus while he proved his existence as a thinking being Descartes failed to establish the existence of his body and the external world with equal certainty and epistemic rigor.

The second inference is that consciousness and the external world constitute two distinct beings - that the cogito is radically different from corporal body and all other extended entities. In the synopsis for the six meditations we read: "I prove that the mind is really distinct from the body (although I show that the mind is so closely joined to the body, that it forms one thing with the body)" (Desecrates, 1979, p.10). The two substances that comprise his nature are so unlike each other. Descartes believes that it was possible to envisage the existence of mind without the body. He states that ultimately, "thought is an attribute that really does belong to me. This alone cannot be detached from me" (Descartes, 1979, pp.18-19).

The doctrine of analogy rests in the belief that since it is impossible to have direct access to other minds, the only mechanism we have to know the other is inferentially. John Stuart Mill, who is the chief representative of the school, noted that:

I conclude that other human beings have feelings like me; first they have bodies like me, which I know, in my own case, to be the antecedent condition of feelings; and because, secondly, they exhibit the acts, and other outward signs, which in my own case I know by experience, to be caused by feelings...experience, therefore, obliges me to conclude that there must be an intermediate link...to be of the same nature as in the case of which I have experience - I bring other human beings as phenomena. (Malcolm, 1963, p.16)

From such observations we can make a safe deduction that the 'reaction' that others show must have been caused by similar internal events like ourselves. In other word, when we perceive similar bodily behavior in the "other" it would be correct to infer that he or she is a subject and that similar things are taking place in her or his mind. In short, inference, deduction and postulation are required to have access to other minds.

Later drawing on Hegel, Husserl and Heidegger, Sartre (BEING and NOTHINGNESS) found the essential corrective measure against the classical school. Their approach was indeed seen by him as a great progress from the old tradition at least in two essential points; they viewed self/other relation as 
essentially connected and the 'other' cannot be an object of knowledge since fundamentally its relation with me is one of being to being. But Sartre of course criticized as he appropriated and naturally found some grounds of disagreement with their work. He contends that even though they made gains over the school, they nevertheless failed to establish the "other as an irreducible fact" and hence end up compromising their work to Idealism.

Among the four philosophers, Hegel comes closer to Sartre regarding this particular issue. This is all the truer since Alexander Kojeve's Lecture on Hegel's phenomenology triggered a revival of Hegelian studies in post-war France. Mark Poster, in his influential book Existential Marxism in Postwar France acknowledged the importance of Kojeve for Sartre's understanding of Hegel. He states "Kojeve was able to put in relief those aspects of Hegel's thought that lead to Marxism and Existentialism" (Poster, 1975, p.16).

As is commonly known, the phenomenology is an ambitious undertaking which tries to trace the dialectic of human consciousness from the lowest stage of its inception up to and including what Hegel calls "Absolute Knowledge." It is neither relevant (for our purpose) nor possible to summarize the spirit of this great work in a few preliminary remarks. What is intended in the following pages is to select the relevant text in the book that clearly demonstrates the connection with Sartre's ontology of selfhood and intersubjectivity.

In Hegel, Sartre found a break and a means to transcend the heritage of Cartesianism. In doing so, because "he places himself on the plane of reciprocal relationship between one consciousness and the other which Descartes does not as, by saying, "I think, therefore I am," he already takes himself for granted" (Lafroge, 1970, p.115). Thus, for Sartre, Hegel made a tremendous gain over the old doctrine by correcting the error that an immediate knowledge of the individual self is possible. In contradistinction to the Cartesian school, Hegel advanced the thesis that: (i) self-awareness is not given directly but can only be achieved through the complex relations and meditations of others; (ii) precisely because a self becomes conscious of its relationship to itself in mutual self-interactions, all relation between two selves or relation with others is not external but internal. Sartre fully accepted the above Hegelian position that emphasizes the point of view that selfconsciousness has pre-condition. He also endorses and expanded Hegel's view that self-consciousness take place in antagonistic and conflictual ambience.

Just as Sartre finds the "I" of the Cogito as being too formal and abstract, Hegel sees the "I" of desire as "an emptiness that receives real content only by negating action that satisfies desire, in destroying, transforming and assimilating the desired non-I" (Kojeve, 1996: 4). So, for Hegel, interaction with objects alone 


\section{Dagnachew Assefa}

does not lead to self-consciousness; objects only leave us with "thingish I" far from the "reflexive movement of the self-awareness." As Kojeve succinctly puts it:

If, then the desire is directed towered a "natural" non-I, the I, too, will be "natural". The I created by the active satisfaction of such a desire will have the same nature as the things toward which that desire is directed. It will be a "thingish" I, a merely living I, an animal I and this natural I, a function of the natural object, can be revealed to itself and to others only as sentiment of self, it will not attain selfconsciousness (Kojeve, 1996, p. 5).

The question is what shape and form does the dialectic of consciousness take in order to transcend such a bare or minimal state of existence? In other words, how would this "I" - the I of desires enrich and transform itself from the simple stage of sentiment to a more complete level of consciousness? Hegel expresses his view to the above question in the following terms:

Self-consciousness exists in and for itself when and only when by the fact that it so exists can another; that is, it exists only in being acknowledged. Each (self-consciousness) is the mediating term to the other, though which each mediates and unites itself with itself. Each is to itself and to the other as immediate self-existing reality, which at the same time exists for itself through this mediation, they recognize themselves as mutually recognizing each other (Hegel, 1977, p.11).

The full import of the above text is explicated in the fourth section of The Phenomenology under heading "Independence and Dependence: Lordship and Bondage." The core idea of the master/slave dialectic underscores the fact that selfconsciousness is dependent on something other than itself.

\section{The Dialectic of the 'Look'}

"Pannwitz is tall, thin, blond; he has eyes, hair, and nose as all Germans ought to have them, and sits formidably behind a complicated writing-table. I, Häftling 174517, stand in his office, which is a real office, shining, clear and ordered, and I feel that I would leave a dirty stain whatever I touched.

When he finished writing he raised his eyes and looked at me. 
From that day I have thought about Doktor Pannwitz many times and in many ways...

Because that look was not one between two men; and if I had known how completely to explain the nature of that look, which came as if across the glass window of an aquarium between two beings who live indifferent worlds. I would also have explained the essence of the great insanity of the third Germany.

(Levi, 1959, pp. 122-23)

The issue of existence of other beings does not require a proof: it should rather be addressed at the level of ontology. As human beings, we have a primordial experience of persons. Just as we apprehend ourselves without the aid of any reflection, we recognize the other also as a subject - all what is needed is simply to clarify and properly articulate the basis of this experience and certitude. We should, then, seek and discover some sort of cogito that connects us to another person. It is only this "enlarged" cogito that would enable me to emerge outside myself into some direct experience of another person.

According to Sartre, the particular experience of the cogito that guarantees or help us establish "the independence of the other" is that of "being-looked-at by another." It is the "look" that makes my experience for the other possible. It is through his "look" that the other person makes himself reveal to me as a being foritself, i.e., a being endowed with subjectivity, consciousness and transcendence. Even though the "look" manifests itself primarily through the eyes, such things like the sound of footsteps or half-opened windows could reveal the phenomenon of the "look." That is why apprehending the "look" does not necessarily mean seeing the nature, i.e. shape, form, color of the eyes, but simply realizing that we are in the presence of the other. In my initial encounter with the other, I do not perceive him as an object first and then recognize him as a subject later. Through his "look," I understand right at the outset that, like me he is "a transcended transcendence." In that he is capable of overcoming things that encounter him and is "an object" to be looked at the same time. Sartre relates:

I am in a public park. Not far away there is a lawn and along the edge of that lawn there are benches. A man passes by those benches. I see this man; I apprehend him as an object and at the same time as a man. What does this signify? What do I mean when I assert that this object 


\section{Dagnachew Assefa}

is man?... If I were to think of him as being only as a puppet, I should apply to him the categories which I ordinarily use to group temporalspatial "things".....perceiving him as a man, on the other hand, is not to apprehend additive relation between the chair and him, it is to register an organization without distance of the things in my universe around that privileged object" (Sartre, 1975, p. 254)

Thus once I notice that he displays some sort of purpose and unity in his dealings and interactions with his surroundings, I know for sure that this unifying entity is the other person. The sheer appearance of the other generates suspicion and alarm since we both mutually desire the "human world." That is why beingfor-others as a mode of existence is quite a risky matter to the "self" since the other continuously wants to circumvent my ability to exist as an active and engaging being. Hence, being-for-itself is all the time in a state of endless struggle and resistance to avoid being reduced into an object for the other. In sum, for Sartre, the other by definition is "the one who looks at me." In his gaze, he robs my world, kills my subjectivity and makes me dependent upon a freedom which is alien to me.

Prior to my encounter with the other, I had everything going on for me. I was in full control of myself, my surroundings and the world at large. Besides, I had the final say over all matters. I was also the source of all meaning and values. In general, I was the lord and master of the Universe. But with the appearance of the other, and his dreadful look, my world is shattered. Everything which was under my world is reconstituted around him. I am consequently negated as a center: my world is torn asunder and taken away from me. Also, he has now become a center about which a total world is organized. I am overwhelmed by his activity. He has displaced me so to speak, and I am no longer in a position to influence my surroundings in any way I want to. My world is robbed in the sense that "the world has a kind of drain hole in the middle of its being and that it is perpetually flowing off through this hole" (Sartre, 1975, p. 256).

As a result my activity is severely curtailed and what I see and encounter around me is not my making. Under his look, I am placed in a strange world and I am engulfed with feelings of alienation. It is as if I am placed in his world rather than mine. In short, I have lost control of my own situation; things have lost their meaning and have become unpredictable. The surroundings which were familiar before have now acquired strange characteristics and even its existence has become probable. 
Now it follows from this that my world is robbed. The mode of being that describes this annihilating and alienating experience of the other is the phenomenon of "shame." Shame appears as a testament of the alienating power of the other. Shame, says Sartre, "is the recognition of the fact that I am indeed that object which the Other is looking at and judging" (Sartre, 1975, p. 261). Thus, for Sartre, shame, as a mode of experience, is a feeling that takes place in a confrontation between myself and the other. Indeed, without the look or the mediation of the other, it would have not been possible to experience shame.

Shame takes place when I realize that I exist for the other or, in Sartre's formulation, when I become a "being-for-the-other." My whole being is restructured when I begin to see myself as the other sees me. In other words, I start seeing myself from the point of view of the other. Hence, I am now he "who the other sees" and knows. I have acquired a nature, an 'outside' and reduced to an object which looks at and judges; shame is, then, the awareness or the ominous recognition that I have become a different being than I was just before his appearance. Sartre offers a classic illustration:

Let us imagine that moved by jealousy, curiosity, or vice I have just glued my ear to the door and looked through a keyhole [...] But all of a sudden I hear footsteps in the hall. Someone is looking at me! What does that mean? It means that I am suddenly affected in my being and that essential modifications appear in my structure (Sartre, 1975, pp. 259-260).

The sheer perspective of the other forces me to pass judgment on myself as an object. His look makes me see myself as he would see me. I see myself in a way that I might have been seen. As a result, "the other is the indispensable mediator between myself and me" (Sartre, 1975, p. 222). Even supposedly that nobody witnessed my act, I would still experience that I might have been seen. Although, the other allows me to apprehend the inaccessible dimension of myself, in the final analysis: "shame therefore realizes an intimate relation of myself to myself" (Sartre, 1975, p. 221). I am the one who is ashamed of what I am doing but I need his mediation to know that structure of my being.

And, furthermore, the other appears as a threat to my own freedom. The foritself is a being of freedom, a pure spontaneity with no fixed essence. But the other does not recognize me for what I am, that is, a subject endowed with freedom. Instead he sees me as an object that he can impart his value judgments. In his fixating look, my freedom to do what I want and be what I like is immensely 


\section{Dagnachew Assefa}

diminished. He has a transcendent power over me-the subjectivity that I enjoyed before his appearance on the scene is now negated. He has transformed me from a being-for-itself to a being-in-itself. My being-in-the-world shows the mark of this negative transformation.

Again through his look, I experience for the first time my objectivity. In other words, I have forfeited my subjectivity. I no longer have the ability to transcend myself or my situation. It is in this sense that we consider ourselves as slaves insofar as we appear to the other. I have become enslaved since I live under his control and liberty; I am his tool-object that can be utilized for his purpose. So the I is "equipmentalized" by the other. I am what he deems to make of me. After alienating my freedom, I have become "a slave to the degree that my being is dependent at the center of a freedom which is not mine and which is the very condition of my being" (Sartre, 1975, p. 267).

The questions whether there is any possibility that I can reassert my subjectivity to salvage my transcendent power, or if am I condemned to permanent servitude in my encounter with the other. For Sartre, I too have the potential to threaten his freedom by reciprocating his look by mine. By confronting the other by my "looks" I in turn can constitute him as an object. In doing so, I would be able to free myself from his bondage. Unfortunately, he in turn can also reverse the situation by looking back at me and make me an object for him.

This endless movement from being-a-look to being looked-at is adopted in Sartre's classic play No Exist, which I am going to present in the next pages. In No Exit the story begins and ends in a large drawing room in hell, the three characters - Garcin, Estelle and Inez - enters the room separately knowing full well that they are all dead and have been sent to hell. What is interesting about these characters is that instead of creating friendship and solidarity they are bent on persecuting and tormenting one another. It somehow seems that the three have been selected and assigned to inflict the maximum pain and torturer on each other.

As the play advances it becomes clear why they are one another's tormenters. Since the central story of the drama focuses on the characters and nature of the subjects evolved it would be appropriate to begin our review by examining the personality of the trio one by one.

Inez is a character that comes from a poor, working-class background that is in an endless pursuit for Estelle's love and affection. As a lesbian-sadist, she not only enjoys seeing others suffer, but also "needs" the pain of others for her distorted and inauthentic existence. She became a sadist because she has internalized the contemptuous look of a homophobic and intolerant society. Sartre hints in the play that instead of accepting society's judgment and condemnation, 
she should have practiced freely her sexual preference. But Inez did not choose to do that and followed a different path. In a sense her sadism was a way of getting back at the hostile culture and a desire to transform the other into an object.

Estelle a murderous coward who is extremely self-centered (narcissistic) with no other interest except trying to find out how others view her. She is entirely dependent on others' perspective of her. She is particularly obsessed in achieving male admiration and confirmation that would give her validation and acceptance by society. Naturally, she turns to Garcin, who is the only male figure around. In Garcin she hopes to find the realization of her burning desire (approval and love) in his arms.

Garcin is a journalist who pursues the cause of pacifism until he is caught and shot trying to flee from his military duty. He is tormented by the question whether he was indeed a pacifist or a coward. He is deeply bothered about his character where a dilemma confronts him there, is his flight upon the outbreak of the war motivated by his moral aversion to violence, or is he simply a coward who lacked courage and fortitude in the face the enemy. The question is so important for him that he played the role of a Don Juan, hoping to prove that he was a "real man."

What is common about the trio is that they all have yearnings-love and recognition - which the other can fulfil but none is able to do so. Each is incapable of giving what the other wants desperately.

Consider the case of Inez; her sexual advances toward Estelle completely fail, as social snob who is highly dependent on male confirmation. Estelle cannot reciprocate her desire. For a woman who spent most of her life seeking and depending on male attraction and validation, Inez will be naturally unacceptable. In fact, if she had her way. Estelle would torment Inez by making love to Garcin.

Inez could retaliate by not giving Estelle the image and affirmation that she needs badly. She jokingly reminds Estelle that: "suppose, I covered my eyes"; or turn my back not to seek you, "you're loveliness" would be a waste. She knows very well that such talks make Estelle nervous and vulnerable. In a memorable line she says of herself: "I feel so queer. [She pats herself.] Don't you ever get taken that way? When I can't see myself I begin to wonder if I really and truly exist. I pat myself just to make sure, but it doesn't help much" (Sartre, 1989, p.19). Beyond Estelle's narcissistic obsession about her self-image and quest for validation, Sartre is also suggesting the fact that they each need the mediation of the other for their existence.

To go back to Inez's saga, her dream of receiving an embracing arm from Estelle is dashed forever and therein lies her torment and frustration. 


\section{Dagnachew Assefa}

Estelle, for her part, does not get her wish realized either. Before Garcin fulfills her desire, he wants her to help him resolve his deep-seated doubt about himself; he needs to be persuaded by her that he is not a coward.

But for Estelle, his character is a non-issue. She is not interested to know whether he is a coward or not; questions of ethics do not have a place in her universe. Her interest in him is to get his love and uninterrupted attention.

Sadly enough for Garcin, the only other person he can turn to is Inez. But in her cold, staring eyes, Inez recognizes his act as cowardice. The same hostile gaze of Inez also makes him incapable of making love to Estelle.

It soon becomes evident to them that they are unable to make any purposeful use of each other. They also found out that hell is far from what they had imagined before. Much to their surprise, there is no "torture-chambers, the fire and brimstone, the "burning marl." Old Wives' tales! There is no need for red-hot pokers. Hell is - other people!" (Sartre, 1989, p. 45). This means that they themselves are one another's tormenters; knowingly or unknowingly, each has created hell for the other.

Garcin expresses their rage and frustration in statements that could be taken as the high climax of the play:

"Estelle: Don't listen to her. Press your lips to my mouth. Oh, I'm yours, yours, yours.

Ineze: Well, what are you waiting for? Do as you're told. What a lovely scene: Coward Garcin holding baby-killer Estelle in his manly arms! Make your stakes, everyone. Will Coward Garcin kiss the lady, or won't he dare? What is the betting? I'm watching you, everybody's watching, I'm a crowd all by myself. Do you hear the crowd? Do you hear them muttering, Garcin? Mumbling and muttering. "Coward! Coward! Coward! Coward!"- that is what they are saying...

Garcin: Will night never come?

Inez: Never

Garcin: You will always see me?

Inez: Always. 
Garcin: ...Yes, now's the moment; I'm looking at this thing on the mantelpiece, and I understand that I'm in hell. I tell you, everything's been thought out beforehand. They knew I'd stand at the fireplace stroking this thing of bronze, with all those eyes intent on me. Devouring me. [He swings round abruptly.] What? Only two of you? I thought there were more; many more. [Laughs.] So this is hell. I'd never have believed it... (Sartre, 1989, pp. 44-45).

The crux of their problem lies in their failure to mutually recognize each other's need. Thus, in as much as they live and act their lives as others see them, instead of being themselves and exercising their freedom as "for-itself," they will not be able to overcome their misery.

It is precisely in this context that we should understand Inez's sadism and Estelle's pathological obsession about her image. As for Garcin, he is no different from the other two. Consider his exchange in the play between him and Estelle:

"Garcin: Estelle, am I a coward?

Estelle: But I don't know, honey, I am not in your shoes. You have to make up your mind for yourself.

Garcin: I can't make up my mind" (Sartre, 1989, p.37).

The play clearly adumbrates the problem of seeking self-affirmation and dependence solely on others. It also shows graphically how our relations with the others could degenerate into torturer and tortured. For Sartre, "the idea that selfreflection is the touchstone of self-recognition and others people and obstacles distorters mirror as it were" (Solomon, 1981, p. 7).

\section{Conclusion}

Even though every exposition presupposes a reading, the procedure I followed up to now had been expository. Henceforth, I shall adopt the role of a critic and engage Sartre mainly about his social ontology that underlines the structure of his "intersubjectivity." In a sympathetic review of Being and Nothingness MerleauPonty suggested to Sartre that his work was exclusively preoccupied with consciousness to the exclusion of the social and historical world; that he had uncritically tied to develop a whole system of philosophy of consciousness. 


\section{Dagnachew Assefa}

He also suggested to him that in the future he should develop "a theory of passivity" and man and his world. Thus, without further development, he feared that "the book remains too exclusively authentic; the antithesis of my view of myself and another view of me and the antithesis of the for-itself and the in-itself after seem to be alternatives instead of being described as the living bond of communication between one term and the other" (Merleau-Ponty, 1964, p.72)

I believe that Sartre took Merleau-Ponty criticism quite to heart and tried to correct the shortcomings of his early writings. Thus, in the critique of Dialectical Reason he stretched his earlier theory to cover a broad range of issues such as man's relations with the material world and group relations. But even though he ventured to confront much broader questions, in the process he encountered serious problems. I submit that one of the main reasons why he faced a problem is that in spite of his adoption of the phenomenological/dialectical method, his habit of formulating his inquiry within a subject/object problematic remained with him to the last.

As David E. Robert succulently put it, "His failure (Sartre's) as a philosopher, if he has failed, is due to the fact that his entire world view rests upon a radical arrangement which is worse than the dualisms he has ostensibly overcome" (Roberts, 1959, p. 197). Indeed, notwithstanding his useful notions of mediations his earlier dualistic stance reappears again and again. As a result, when analyzing key philosophical problems, he undermines the complexity of the problem and ends up resolving "complexity into types." Thus, for example, just like his earlier view, he comes perilously close in endorsing the belief that human beings are either totally free or totally in bondage.

Second, Sartre's later work never fully resolved the "tension" between his earlier formal categories that represent the power of consciousness and "those built around to accommodate the force of circumstances. As a leading Sartre scholar Thomas W. Busch, alleges that Sartre to the end never fully worked out the relationship between "Being-in-the-world and the cogito" (Busch, 1990, p. 77).

Third, in Sartre's notion of the look there is a tendency by consciousness to posit everything as an object. In addition, we are permanently tossed from one state of affairs to the other i.e. from being a look to being looked at. Thus human relationship is always instable and fluid since we cannot be subject and object at the same time. Whenever the other emerges as a subject, he ceases to be an object. As a subject, he is beyond my control and that is why Sartre says that the existence of the other is a scandal for me.

Whatever way we look at it, the chance of establishing "I and thou" relationship with the other is doomed to failure. I either transcend the other's 
subjectivity or let myself be transcended by him. As a subject we have no use for each other, in the end, either the other reduces me to an object or I annihilate his subjectivity and make him an object for me.

All efforts to neutralize the freedom of the other in the end fail to materialize. Even "love" does not succeed in this respect since it is quite impossible to attain the level of intimacy and affection which is free from a relationship of domination. Instead, the adversarial nature of my relation with the other leads into two kinds of reaction; sadism and masochism. Caught between these two ways, we never overcome the threat of the other.

Since the other is intractable to any fraternal identification, concrete relationship with others is merely provisional if not impossible. In the final analysis, all relations inevitably end up in some form of conflict. Sartrean "systems" are devoid of any transcendent category that could be the bases for an optimistic human relationship. Thus for Sartre, the essence of human relationship is not being together but conflict.

Consider No Exit we find the same pessimistic conclusion in the play in one scene and three characters, it succeeds remarkably well in capturing the essence of Sartre's teachings about human relationship. In it we find Sartre's complicated theory of the "look" with all its devastating effect on human subjectivity and human freedom being acted out as each character lives and relates her/his existence in hell. It is as though we are permanently condemned to a tragic failure attaining a peaceful and harmonious community.

Sartre complains that some people incorrectly interpret the expression Hell is the other people literally. Consequently, he alleges they attribute to him "pessimism" that is quite remote from what he had originally intended. He writes: "Hell is other people have always been misunderstood. People thought that what I meant by it is that our relations with others are always rotten, illicit. But I mean something entirely different. I mean that if our relations with others are twisted or corrupted, then others have to be hell" (Contat \& Rybalk, 1974, p. 99). But Sartre's explanation is questionable because No Exit does not offer an alternative reading other than the gloomy picture that is epitomized in Garcin's utterance.

To be sure, No exit is not the last statement that Sartre made about human relationship but the kind of picture that is depicted in the play is quite consistent with what we find in Being and Nothingness. Both texts offer the destructive side of human relationship in a clear and unambiguous manner. 
References

Busch, T. (1990). The power of consciousness in Sartre's philosophy. Bloomington and India Polish: Indiana University Press.

Contat, M., \& Michel R. (1974). The writing of Jean-Pole Sartre (Vol. 2). (McCleary, R. Trans.). Evanston: Northwestern Univ. Press.

Daigle, C. (2010). Jean-Paul Sartre: Rutledge critical thinkers. Rutledge Publisher.

Descartes, R. (1979). On first Philosophy. (Miller, A.V. Trans.). Indian Polish: Hack Pub. Company.

Hegel, G. (1979). Phenomenology of the sprit. (Miller, A.V. Trans.). New York: Oxford University Press.

Kojeve, A. (1996). Introduction to the reading of Hegel: Lecture on the phenomenology of the spirit. (Bloom, A. Trans.). New York: Basic Books, Inc., Publishers.

Lafroge, R. (1970). Jean-Pole Sartre: His philosophy. Notre Dame Univ. Press.

Levi, Primo. (1959). If this is a Man. New York: The Orion Press.

Malcolm, N. (1958). Problems of mind: Descartes to Wittgenstein. New York: Harper Torch Book.

Merleau-Ponty, M. (1964). Sense and non-Sense (Studies in phenomenology and existential philosophy). (Derefus, Huber L., \& Patricia Allen Dreyfus, Trans.). Northwestern University Press.

Poster, M. (1975). Existential Marxism in postwar France: From Sartre to Althusser. New Jersey: Princeton University Press.

Robert, D. (1959). Existentialism and religious belief. New York: Oxford Univ. Press.

Sartre, J. (1959). Nausea. (Alexander, L., Trans). New York: New Direction.

Sartre, J. (1975). Being and nothingness: A phenomenological essay on ontology. (Hazel, B., Trans.). Washington: Square Press.

Sartre, J. (1989). No Exit and Tree Other Plays. (Abel, I., Trans.). New York: Vintage International.

Solomon, R. (1981). Introducing the existentialists: Imaginary interviews with Sartre, Heidegger and Camus. Indianapolis: Hackett Pub. 